\title{
In Vitro Assessment of Antioxidative Potential of Goat Milk, Casein and its Hydrolysates: Comparison of Goat Milk with Bovine and Buffalo milk
}

\section{Sunny Kalyan}

National Dairy Research Institute

SUNITA MEENA ( $\square$ sunitameena1188@gmail.com )

National Dairy Research Institute https://orcid.org/0000-0003-1845-031X

\section{Suman Kapila}

National Dairy Research Institute

\section{Radha Yadav}

National Dairy Research Institute

\section{Gaurav Kr Deshwal}

National Dairy Research Institute

\section{Research Article}

Keywords: Goat milk, cow milk, buffalo milk, casein hydrolysates, antioxidative potential

Posted Date: June 1st, 2021

DOI: https://doi.org/10.21203/rs.3.rs-546200/v1

License: (c) (i) This work is licensed under a Creative Commons Attribution 4.0 International License.

Read Full License

Version of Record: A version of this preprint was published at Indian Journal of Dairy Science on October 31st, 2021. See the published version at https://doi.org/10.33785/IJDS.2021.v74i05.004. 


\section{Abstract}

The present study was executed with an aim to explore the antioxidative potential of goat, cow, and buffalo milk. Buffalo milk has showed highest antioxidative potential than goat and cow milk as measured by ABTS, ORAC, and DPPH assays, whereas goat milk has showed better antioxidative potential than cow milk when measured by ORAC and DPPH. Further, the effect of temperature on the antioxidative potential of goat milk was assessed. An increase in temperature has a negatively affect the antioxidative potential of goat milk. The antioxidative potential of goat milk was in the following order: raw milk > pasteurized milk > boiled milk. Casein derived from goat milk by isoelectric precipitation was hydrolyzed by gastrointestinal enzymes pepsin (P), trypsin ( $T$ ), chymotrypsin (C), and their combinations PT, PC, TC, and PTC. Among all the casein hydrolysates, the maximum antioxidative potential was found in PT hydrolysate, further fractionated by 10,3 and $1 \mathrm{kDa}$ ultrafiltration membranes. 3-10 kDa fraction exhibited maximum antioxidative potential in comparison to other fractions of PT hydrolysate. Our results suggested that antioxidative potential of goat milk and its hydrolysates could be an important mean to obtain natural antioxidative peptides.

\section{Introduction}

Oxidative stress is a physiological disproportion of evolvement of reactive oxygen species (ROS) and their neutralization by the antioxidative system. This imbalance has been closely linked with alzheimer's, atherosclerosis, cardiovascular disease, diabetes, huntington, rheumatoid arthritis, and other age-related diseases (Kasparova et al., 2005; Fitzpatrick et al., 2009). The excessive increase in ROS levels can induce oxidative stress by oxidizing membrane lipids, cellular proteins, DNA in the body. Replenishing antioxidants to balance the ROS and antioxidative systems may help combat abovementioned disease conditions (Yu, 1994). Thus, antioxidant-enriched food products are becoming increasingly popular. Previous studies have demonstrated that food components, including ascorbic acid (vitamin $\mathrm{C}$ ), $\beta$ carotenes, tocopherols, polyphenols, and bioactive peptides, have protective effects against oxidative stress and, therefore, act as antioxidants (Valko et al., 2007; Simos et al., 2011).

Goat milk production has shown an upsurge worldwide and highly preferable owing to its antiallergenicity especially in infants while comparing with cow milk (Almaas et al., 2006; Park, 2009; Simos et al., 2011) also anti-platelet, antibacterial, immunomodulatory and antioxidative capacity (Amati et al., 2010; Anas et al., 2008; Kullisaar et al., 2003; Simos et al., 2011; Meena et al., 2019). Additionally, goat milk has manifested diverse biological properties in comparison to different species milk including human, such as high buffering capacity, dissimilar alkalinity (Park, 2009; Park and Haenlien, 2008), higher digestibility because of small size fat globules (Meena et al., 2014) and higher amount of short and medium chain fatty acids which are linked with hypocholesterolemic function in humans, by preventing cholesterol deposition and enhancing its movement and excretion (Haenlein 2004; Kalyan et al., 2018). Therefore, due to goat milk's nutritional and bio-functional properties, it has received extensive attention. The antioxidative properties of goat milk are reported higher than bovine and donkey milk (Simos et al., 2011). Previously, the anti-atherogenic effects of fermented goat milk proteins in humans 
have been demonstrated (Kullisaar et al., 2003). These beneficial effects occur due to the release of bioactive compounds as goat milk is readily digestible and absorbed in the gut and small intestine, respectively (Park, 2009).

The amino acids liberated during fermentation or enzymatic hydrolysis exert numerous health benefits and circumvents chronic illnesses due to their ACE inhibitory, antioxidative, antibacterial, and immunomodulatory activities (Korhonen and Pihlanto, 2006; Atanasova and Ivanova, 2010). Bioactive peptides from bovine milk are extensively known (Power et al., 2013), but in recent times, studies have also been conducted on non-bovine species such as camel, sheep, donkey and goat (Mudgil et al., 2018; Li et al., 2013; Atanasova and Ivanova, 2010). Goat milk proteins have shown presence of peptides with antimicrobial, antioxidative, antidiabetic, ACE inhibitory and immune-modulating properties (Mudgil et al., 2018; Atanasova and Ivanova, 2010; Li et al., 2013; Santillo et al., 2009; Park, 2009). A few studies have reported antioxidative peptides from goat milk protein. A total five antioxidative peptides were identified in goat milk casein hydrolysate after digestion with two enzymes namely, Alcalase and Pronase however, four reported peptides didn't correspond to sequences in goat casein databases (Li et al., 2013).

Kusumaningtyas et al., (2016) performed enzymatic digestion with pepsin, trypsin, chymotrypsin and by Bacillus sp.E.13 protease indicating antimicrobial and antioxidative potential of Bacillus sp.E.13 protease against other enzymes. The bioactive peptides of non-bovine species milk and their milk products were comprehensively reviewed recently (Guha et al., 2021). Previously, studies pertaining to antioxidative potential of goat milk has been performed. However, in present study all the commonly accepted antioxidative assays (FRAP, ABTS, DPPH and ORAC) have been performed to compare the antioxidative potential of goat milk with cow and buffalo milks. Along with, the effect of different degree of thermal treatment on antioxidative capacity of goat milk has also been performed. Further, antioxidative potential of goat milk casein and its hydrolysates and most potent antioxidative fraction of goats' milk casein obtained by enzymatic digestion with pepsin, trypsin and chymotrypsin individually and in combination.

\section{Materials And Methods}

\section{Procurement of chemicals}

Flourescein disodium salt, trolox, o-phthaldialdehyde, ABTS $\{2,2$ '-azinobis-(3-ethyl-benzothiazoline-6sulphonic acid)\}, BCA sodium salt, AAPH (2,2-Azobis(2-aminopropane) dihydrochloride, TPTZ (2,4,6-tri [(2pyridyl)-s-triazine], DPPH (2,2-Diphenyl-1-picrylhydrazyl), commassie brilliant blue dye, trypsin and chymotrypsin were procured from Sigma-Aldrich Chem. Co., St Louis, MO, USA. Pepsin was procured from Sisco Research Laboratories, Mumbai, India.

\section{Procurement and processing of milk}

Raw milk of goat (crossbred of Alpine $\times$ Beetal), cow (Sahiwal breed) and buffalo (Murrah breed) were procured from the Livestock Research Centre, ICAR-National Dairy Research Institute, Karnal Haryana 
(India), and fat content was adjusted to $3 \%$ for all samples owing to variability in fat-soluble antioxidants such as tocopherols, retinol and carotenoids with varying fat percentage (Noziere et al., 2006; ChauveauDuriot et al., 2010). The antioxidant potential of raw, pasteurized $\left(63^{\circ} \mathrm{C} / 30 \mathrm{~min}\right)$ and boiled milk $\left(100^{\circ} \mathrm{C}\right.$ for no-hold) was also assessed using the undermentioned assays.

\section{Assays to measure anti-oxidative capacity of milk from different species}

The following four different assays were employed for measuring the anti-oxidative potential of milk from different species.

\section{ABTS assay}

ABTS assay was executed as per the methodology indicated by Re et al., (1999) wherein, exactly $20 \mu \mathrm{L}$ of the sample (diluted 10 times) was mixed with $180 \mu \mathrm{L}$ of diluted ABTS ${ }^{\circ+}$ solution. The mixture was stirred for $5 \mathrm{sec}$ and the absorbance was measured at $750 \mathrm{~nm}$ after $10 \mathrm{~min}$. Percent inhibition was calculated. Trolox standard was used in the range of 50 to $500 \mu \mathrm{M}$ at an interval of $50 \mu \mathrm{M}$. Trolox equivalent antioxidant capacity (TEAC) of the samples was evaluated from the standard curve of Trolox (50 to 500 $\mu \mathrm{M})$ based on the inhibition percentage. The standard curve equation was $y=0.187 x-3.818\left(R^{2}-0.994\right)$.

\section{Oxygen radical absorbance capacity-Fluorescein (ORAC-FL) assay}

ORAC assay was performed via fluorescein as per the procedure of Ou et al., (2002) and Davalos et al., (2004). Exactly, $20 \mu \mathrm{L}$ of sample (diluted 10 times) was mixed with $120 \mu \mathrm{L}$ fluorescein $(1.17 \mu \mathrm{M})$ in a black 96 well microplate. Thereafter, storage at $37^{\circ} \mathrm{C}$ for $15 \mathrm{~min}$ and mixing of $60 \mu \mathrm{L}$ of AAPH $(2,2-$ Azobis(2-aminopropane) dihydrochloride) solution (12 mM strength) was performed. The decay in fluorescence was recorded at $495 \mathrm{~nm}$ and $520 \mathrm{~nm}$ excitation wavelength. The fluorescence values of the samples were normalized to the blank curve. As per the normalized curves, the area under the fluorescence decay curve was measured. The trolox standard was used in the range of 10 to $100 \mu \mathrm{M}$ at an interval of $10 \mu \mathrm{M}$. The standard curve equation was $y=0.328 x+1.635\left(R^{2}-0.991\right)$.

\section{Ferric Reducing Antioxidant Power (FRAP) activity}

The FRAP activity was performed as per the methodology of Benzie and Strain (1996), with minor amendments. Exactly, $90 \mu \mathrm{L}$ milk sample was added to $2.7 \mathrm{~mL}$ FRAP reagent and $210 \mu \mathrm{L}$ water was mixed prior to incubation at $25^{\circ} \mathrm{C}$ for $30 \mathrm{~min}$ in the dark and absorbance at $593 \mathrm{~nm}$ was recorded. The 
trolox standard was used in the range of 0.08 to $0.72 \mu \mathrm{M}$ at an interval of $0.08 \mu \mathrm{M}$. The standard curve for Trolox was $y=1.017 x+0.022\left(R^{2}-0.989\right)$.

\section{DPPH activity}

The antioxidant capacity established on DPPH radical for milk samples was analyzed by methods defined by Thaipong et al., (2006) and Zhidong et al., (2013) with slight modifications. Trolox standard was used in the range of $100-800 \mu \mathrm{M}$. The standard curve equation was $y=0.107 x+3.529\left(R^{2}-0.993\right)$.

\section{Screening of casein hydrolysates for anti-oxidative activity}

\section{Isolation of goat milk casein}

Isoelectric precipitation method was utilized for separating the casein of goat milk (Davies and Law, 1977). The concentration of goat milk casein was evaluated by Lowery method using the standard curve i.e., $y=0.001 x+0.054\left(R^{2}-0.992\right)$. The purity of the casein derived from goat milk was tested by Sodium Dodecyl Sulphate-Polyacrylamide Gel Electrophoresis (SDS-PAGE) in a vertical slab gel electrophoresis system (Laemmli et al., 1970). After the completion of electrophoresis, protein bands present in the gel were stained with Coomassie brilliant blue staining solution for $30 \mathrm{~min}$ and bands were observed after overnight de-staining.

\section{In vitro hydrolysis of casein protein}

Isoelectrically precipitated caseins were hydrolyzed with pepsin, trypsin, chymotrypsin, and their different combinations (Jinsmaa and Yoshikawa, 1999), with slight modifications. Before carrying out the hydrolysis of protein by the enzymes and their combinations, the time duration of complete hydrolysis by each enzyme was standardized. Pepsin, trypsin, and chymotrypsin were mixed with pre-incubated casein solution ( $1 \mathrm{mg} \mathrm{mL}^{-1}$ ) in the ratio of 1:100 (E:S), followed by incubation at $37^{\circ} \mathrm{C}$ for $8 \mathrm{~h}$ using a water bath with continuous mixing. Thereafter, samples were collected at varying time breaks $(0,1,2,4,6$ and $8 \mathrm{~h})$. The degree of hydrolysis was calculated by evaluating the free amino groups released during hydrolysis by the OPA method (Church et al., 1983). Thereafter, casein was hydrolyzed by the enzymes and their combinations for $3 \mathrm{~h}$ by following the same procedure as described above. For pepsin combination with other enzyme, firstly the casein was hydrolyzed with pepsin at $2.0 \mathrm{pH}$ for $3 \mathrm{~h}$ followed by increment of $\mathrm{pH}$ to 8.0 using $1.0 \mathrm{~N} \mathrm{NaOH}$ and then allowing the digestion with other enzymes subsequently for $3 \mathrm{~h}$ each. After incubation, the reaction was terminated by enhancing the $\mathrm{pH}$ to 8.0 by $1.0 \mathrm{~N} \mathrm{NaOH}$ for pepsin, while trypsin and chymotrypsin activity was inhibited by raising the temperature to $98^{\circ} \mathrm{C}$ for $10 \mathrm{~min}$. Peptide concentration in the hydrolysates was estimated by Bicinchoninic acid (BCA) assay (Smith et al., 1985). Briefly, $10 \mu \mathrm{L}$ of sample was mixed with $190 \mu \mathrm{L}$ BCA reagent (1:19) in 96-well ELISA plate and incubated 
at $37^{\circ} \mathrm{C}$ for $30 \mathrm{~min}$. ELISA plate was cooled to room temperature and the absorbance was recorded at 562 $\mathrm{nm}$. The peptide concentration in the hydrolysates was evaluated using the standard curve of BSA $(y=$ $0.048 x+0.023$ with an $R^{2}$ of 0.987$)$. Further, Tricine Sodium Dodecyl Sulphate-Polyacrylamide Gel Electrophoresis (Tricine SDS-PAGE) was performed to detect low molecular weight peptides in hydrolysates (Pardo and Natalucci, 2002). Furthermore, isolated casein was used for further studies.

\section{In vitro evaluation of the casein and its hydrolysates}

Anti-oxidative activity of the casein and its hydrolysates was evaluated by ABTS, ORAC and DPPH assay as described above.

\section{Ultrafiltration of Pepsin-Trypsin hydrolysates}

Pepsin-Trypsin hydrolysates of casein with maximum anti-oxidative activity were purified using ultrafiltration. Pepsin-Trypsin hydrolysate of casein were ultrafiltered by 10, 3 and $1 \mathrm{kDa}$ molecular weight cut-off (MWCO) membrane which fractionated the casein hydrolysate based on their size and also eliminated the enzyme and non-hydrolyzed proteins from the reaction mixture (Segura-Campos et al., 2011). The ultra-filtrated peptide fractions so obtained were labelled as $>10 \mathrm{kDa}$ (10 kDa retentate), 3-10 $\mathrm{kDa}$ (3 $\mathrm{kDa}$ retentate), 1-3 kDa (1 kDa retentate) and < $1 \mathrm{kDa}$ (1 kDa permeate) as described in Figure 1. The antioxidant activity of each fraction was measured as discussed previously.

\section{Results And Discussion}

The antioxidative potential of goat milk was evaluated, and a comparison was performed with cow and buffalo milk thereof. Differently, heat-treated goat milk viz. raw, pasteurized, and boiled goat milk was evaluated for its antioxidative potential. Further, goat milk casein derived hydrolysates were also evaluated.

\section{Anti-oxidative potential of milk}

The antioxidative properties of milk were measured in terms of TEAC using ABTS, ORAC, FRAP and DPPH assay. Results revealed improved antioxidative potential of buffalo milk as compared to cow and goat milk using all the four assays (Table 1). However, goat milk showed better antioxidative potential than cow milk when evaluated using ORAC and DPPH assay. Besides the contribution of water-soluble compounds namely phenols, ascorbate, and low-molecular weight thiols, it is well established that TEAC also depends on milk fat components, which encompasses various fat-soluble antioxidants such as tocopherols, retinol, and carotenoids (Noziere et al., 2006; Chauveau-Duriot et al., 2010), casein and whey proteins (Suetsuna et al., 2000; Pihlanto, 2006), although in present study fat was adjusted to constant value of $3 \%$ for all milk samples. Therefore, the detected variations in TEAC might be attributed to 
variation in species-specific milk composition particularly, protein and other potential antioxidative compounds (Niero et al., 2018). The differences among diverse assays could also be due to their quantifying parameters. Huang et al. (2005) reported that antioxidative assays are majorly of two types i.e., dependent on hydrogen atom transfer reactions and electron relocation reactions. Thus, it is suggested that ABTS, FRAP and DPPH should be utilized to measure antioxidant reducing capacity and ORAC assay to evaluate peroxyl radical scavenging potential of antioxidant. Our results are in confirmation with Alyaqoubi et al. (2014) who had found significantly higher $(p<0.05)$ antioxidant activity of goat milk than cow milk using DPPH and FRAP assay. Similarly, Simos et al. (2011) claimed better antioxidative capacity of goat (Prisca breed) milk as compared to cow milk reflecting higher bioavailability of antioxidant compounds in goat milk. In present study, FRAP assay showed converse result with goat milk possessing significantly $(P<0.05)$ higher antioxidative activity in comparison with buffalo milk but non-significantly $(P>0.05)$ dissimilar from cow milk (Table 1$)$.

Further, antioxidative potential of pasteurized and boiled goat milk declined in comparison to raw goat milk when estimated by ABTS, ORAC, FRAP and DPPH assay. The antioxidative potential by ABTS of pasteurized goat milk and boiled goat milk was $4964 \pm 36.44$ and $4749 \pm 21.22$, respectively thus signifying inverse relationship between antioxidative potential and degree of heat treatment. Raw goat milk had the highest antioxidative activity followed by boiled and pasteurized goat milk as measured by ABTS and DPPH assay (Table 2). Heat treatment has detrimental effects on the antioxidative properties of goat milk and it is reported that higher temperature short time treatments can deplete the overall antioxidative properties of milk. Contrarily, high heat treatment facilitates the Maillard reaction between nucleophilic group of amino acids and carbonyl group of reducing sugars and these Maillard reaction products i.e., brown melanoidins, enhance recovery and possible elevation of antioxidative properties (Calligaris et al., 2004; Zulueta et al., 2009). Alyaqoubi et al. (2014) assessed the impact of heat treatment on antioxidative potential of milk and reported lower antioxidative potential of pasteurized milk than unpasteurized milk and reduced phenol and flavonoids content in pasteurized milk.

\section{Preparation and screening of casein hydrolysates}

Goat milk casein was isolated by isoelectric precipitation and concentration in goat milk sodium caseinate was $270 \mathrm{mgmL}^{-1}$ as determined by Lowery method. Then, the purity of the casein samples was evaluated by $15 \%$ Sodium Dodecyl Sulphate-Polyacrylamide Gel Electrophoresis (Fig.2). Different digestive enzymes such as pepsin (P), trypsin $(T)$, chymotrypsin $(C)$ and their combinations were employed to hydrolyze isoelectrically precipitated casein for peptides formation. The hydrolysis rate of casein protein by trypsin and chymotrypsin increased with time and almost got saturated after $3 \mathrm{~h}$ of incubation (Fig. 3), but hydrolysis by pepsin persisted even after $3 \mathrm{~h}$, although the hydrolysis rate was slightly lower. Consequently, duration of hydrolysis was standardized to $3 \mathrm{~h}$ for the experiments owing to maximal degree of hydrolysis during this duration (Fig.3). Shanmugam et al., (2015) also reported similar findings in their study. Similarly, the antioxidant peptides were liberated maximally at $3 \mathrm{~h}$ while digesting casein with pepsin and trypsin (Ming and Zhi-he et al., 2012). The degree of hydrolysis of goat milk 
casein hydrolyzed by P, T, C, PT, PC, TC and PTC were $2.84 \pm 0.210 \%, 5.29 \pm 0.194 \%, 5.85 \pm 0.048 \%, 6.27 \pm$ $0.127 \%, 5.07 \pm 0.073 \%, 7.19 \pm 0.250 \%$ and $8.53 \pm 0.127 \%$, respectively (Fig. 4). The extent of hydrolysis of intact casein using trypsin, chymotrypsin and all the combinations was significantly higher as compared to pepsin. The degree of hydrolysis was in the range of 7.10 to $17.60 \%$ for buffalo milk casein hydrolyzed by P, T, C singly and their combinations (Shanmugam et al., 2015). Variations were attributed to enzyme specificity for cleavage site and the quantum of sites available in respective proteins. Preferential cleavage of a peptide bond between hydrophobic amino acids residues of leucine, phenylalanine, and tyrosine is catalyzed by pepsin (Dunn, 2002). Similarly, chymotrypsin hydrolyses the protein sites having hydrophobic amino acids (Cassidy et al., 1997; Kitts, 1994). The specificity of trypsin is solely limited to hydrophilic amino acid residues of arginine and lysine (Olsen et al., 2004). The yield (\%) of the peptides after hydrolysis by P, T, C, PT, PC, TC and PTC were 19.51 $\pm 0.565,22.24 \pm 1.012,20.15$ $\pm 0.548,18.90 \pm 0.308,17.58 \pm 0.356,18.19 \pm 0.638$ and $17.83 \pm 0.116 \%$ respectively (Fig. 5) estimated by BCA method. Casein hydrolysis was visually evaluated by tricine SDS-PAGE to determine the low molecular weight peptides in hydrolysate and to ascertain hydrolysis of casein by different enzymes as previously determined by OPA method. It was observed that casein was completely hydrolyzed during this digestion process by pepsin, trypsin, and chymotrypsin as depicted in Fig. 6.

\section{Anti-oxidative property of casein hydrolysates}

The antioxidative potential of casein hydrolysates was analyzed on the basis of free radical scavenging activity using ABTS, DPPH, and ORAC (Table 3). In ABTS, ORAC, and DPPH assay, TEAC of hydrolysates was between 0.736 to $0.804 \mu \mathrm{mol} \mathrm{mg}{ }^{-1}, 0.352$ to $0.402 \mu \mathrm{mol} \mathrm{mg}{ }^{-1}$ and 2.745 to $4.381 \times 10^{-3} \mu_{\mathrm{mol} \mathrm{mg}}^{-1}$ of the casein hydrolysates, respectively, whereas the values of unhydrolyzed casein were $0.528,0.347$, and $1.598 \times 10^{-3} \mu \mathrm{mol} \mathrm{mg} \mathrm{m}^{-1}$ as measured by ABTS, ORAC, and DPPH assay, respectively. Similarly, the antioxidative activity of casein hydrolysates obtained from $\mathrm{P}, \mathrm{T}, \mathrm{C}$, and their mixture got enhanced significantly in comparison to unhydrolyzed casein when evaluated using ABTS and DPPH assay (Table 3). The TEAC values of buffalo milk based hydrolyzed casein obtained by pepsin, trypsin and chymotrypsin enzymes were higher than unhydrolyzed buffalo milk casein (Rajesh et al., 2010; Shanmugam et al., 2015). The ABTS assay yielded higher antioxidative activity of the hydrolysates obtained from PT and PC than P, T, C, TC, and PTC hydrolysates. However, the antioxidative assay of PC hydrolysate was significantly $(\mathrm{P}<0.05)$ lower than PT hydrolysate when analyzed using DPPH assay, therefore PT hydrolysate was opted for further purification.

\section{Purification of pepsin-trypsin (PT) hydrolysate of casein by ultrafiltration and assessment of antioxidative potential of different fractions}

PT hydrolysate of casein possessed maximum antioxidative activity which was further purified using ultrafiltration. The obtained fractions were further analyzed for their antioxidative capacity. The PT 
hydrolysate was also ultrafiltered using $10 \mathrm{kDa}, 3 \mathrm{kDa}$, and $1 \mathrm{kDa}$ MWCO to separate enzyme and nonhydrolyzed protein from the reaction mixture and fractionation of casein hydrolysate based on their size. Antioxidative activity of ultrafiltration fractions of PT hydrolysate was assessed by ABTS assay. Antioxidative activity of 3-10 kDa fraction was significantly $(P<0.05)$ higher than all the other fractions and PT hydrolysate (Fig.7). Our findings are in agreement with Shanmugam et al. (2015), who also chose PT hydrolysate of buffalo milk casein for ultrafiltration and reported highest antioxidative activity of 1 kDa permeate as evaluated using ABTS assay. Sun et al. (2011) reported that out of four fractions the $\mathrm{PHH}-\mathrm{IV}$ fraction that is $3 \mathrm{kD}$ a permeate has higher inhibitory effect of lipid peroxidation and scavenging effect on superoxide radical. Similarly, Kusumaningtyas et al. (2016), observed the variations in the antioxidative capacity of goat milk protein hydrolysates based on the technique used and reported the maximum activity of 10-30kDathan $3 \mathrm{kDa}$ as analyzed using ABTS and DPPH, respectively. The higher activity of $<1 \mathrm{kD}$ a peptides in antioxidant assays may be due to higher amount of total hydrophobic and aromatic amino acids as these amino acids' types exhibited more antioxidative activity (Ajibola et al., 2011).

\section{Conclusion}

The present study revealed better antioxidative potential of goat and buffalo milk in comparison to cow milk. However, it could not be ascertained that which milk species has higher antioxidative potential in totality as TEAC depends on number of compounds besides proteins and their composition. Temperature adversely influences the antioxidative capacity and follows inverse relationship with the latter. Antioxidative potential increased upon hydrolysis of goat milk casein. Further, pepsin-trypsin (PT) hydrolysate of goat milk casein exhibited the maximum antioxidative potential than other hydrolysates. PT hydrolysate fraction 3-10 kDa fraction could be utilized to develop physiologically functional foods or therapy drugs. The identification of more potent antioxidative peptides of 3-10 kDa fraction of PT hydrolysate and their bioavailability and antioxidative effect has to be studied both ex vivo and in vivo.

\section{Statistical analysis}

The differences among the treatments were evaluated using one way ANOVA and considered statistically significant at $5 \%$ level of significance.

\section{Declarations}

\section{Acknowledgements}

We thank the technical officers namely Dr. Ravikant Saini and Dr. Rakesh Kumar Raman for instrument handling and statistical analysis, respectively.

\section{Funding}




\section{Consent for publication}

All authors have given their consent for this work to be published.

\section{Conflict of interest}

The authors declare no competing interests.

\section{Data Availability Statement}

The dataset generated during and/or analyzed during the current study are available from the corresponding author on reasonable request.

\section{Author's contributions}

Sunny Kalyan- Methodology, formal analysis and investigation; Sunita Meena- Conceptualization, writing original draft and project administration; Suman Kapila- Supervision; Radha Yadav- Supervision; Gaurav Kr Deshwal- Writing-review and editing.

\section{References}

1. Ajibola, C. F., Fashakin, J. B., Fagbemi, T. N., \& Aluko, R. E. (2011). Effect of peptide size on antioxidant properties of African yam bean seed (Sphenostylis stenocarpa) protein hydrolysate fractions. International Journal of Molecular Sciences, 12(10), 6685-6702.

2. Almaas, H., Cases, A. L., Devold, T. G., Holm, H., Langsrud, T., Aabakken, L., \& Vegarud, G. E. (2006). In vitro digestion of bovine and caprine milk by human gastric and duodenal enzymes. International Dairy Journal, 16(9), 961-968.

3. Alyaqoubi, S., Abdullah, A., Samudi, M., Abdullah, N., Addai, Z. R., \& Al-Ghazali, M. (2014). Effect of different factors on goat milk antioxidant activity. International Journal of ChemTech Research, 6(5), 3091-3196.

4. Amati, L., Marzulli, G., Martulli, M., Tafaro, A., Jirillo, F., Pugliese, V., \& Jirillo, E. (2010). Donkey and Goat Milk Intake and Modulation of the Human Aged Immune. Current Pharmaceutical Design, 16, 864-869.

5. Anas, M., Eddine, H. J., \& Mebrouk, K. (2008). Antimicrobial activity of Lactobacillus species isolated from Algerian raw goat's milk against Staphylococcus aureus. World Journal of Dairy \& Food Sciences, 3(2), 39-49. 
6. Atanasova, J., \& Ivanova, I. (2010). Antibacterial peptides from goat and sheep milk proteins. Biotechnology \& Biotechnological Equipment, 24(2), 1799-1803.

7. Benzie, I. F., \& Strain, J. J. (1996). The ferric reducing ability of plasma (FRAP) as a measure of "antioxidant power": the FRAP assay. Analytical Biochemistry, 239(1), 70-76.

8. Calligaris, S., Manzocco, L., Anese, M., \& Nicoli, M. C. (2004). Effect of heat-treatment on the antioxidant and pro-oxidant activity of milk. International Dairy Journal, 14(5), 421-427.

9. Cassidy, C. S., Lin, J., \& Frey, P. A. (1997). A new concept for the mechanism of action of chymotrypsin: the role of the low-barrier hydrogen bond. Biochemistry, 36(15), 4576-4584.

10. Chauveau-Duriot, B., Doreau, M., Nozière, P., \& Graulet, B. (2010). Simultaneous quantification of carotenoids, retinol, and tocopherols in forages, bovine plasma, and milk: validation of a novel UPLC method. Analytical and Bioanalytical Chemistry, 397(2), 777-790.

11. Church, F. C., Swaisgood, H. E., Porter, D. H., \& Catignani, G. L. (1983). Spectrophotometric assay using o-phthaldialdehyde for determination of proteolysis in milk and isolated milk proteins. Journal of Dairy Science, 66(6), 1219-1227.

12. Dávalos, A., Gómez-Cordovés, C., \& Bartolomé, B. (2004). Extending applicability of the oxygen radical absorbance capacity (ORAC- fluorescein) assay. Journal of Agricultural and Food Chemistry, 52(1), 48-54.

13. Davies, D. T. \& Law, A. J. R. (1977). An improved method for the quantitative fractionation of casein mixtures using ion-exchange chromatography. Journal of Dairy Research, 44(2), 213-221.

14. Dunn, B. M. (2002). Structure and mechanism of the pepsin-like family of aspartic peptidases. Chemical Reviews, 102(12), 4431-4458.

15. Fitzpatrick, A. M., Teague, W. G., Holguin, F., Yeh, M., Brown, L. A. S., \& Program, S. A. R. (2009). Airway glutathione homeostasis is altered in children with severe asthma: evidence for oxidant stress. Journal of Allergy and Clinical Immunology, 123(1), 146-152.

16. Guha, S., Sharma, H., Deshwal, G. K., \& Rao, P. S. (2021). A comprehensive review on bioactive peptides derived from milk and milk products of minor dairy species. Food Production, Processing and Nutrition, 3(1), 1-21.

17. Haenlein, G. F. W. (2004). Goat milk in human nutrition. Small Ruminant Research, 51(2), 155-163.

18. Huang, D., Ou, B., \& Prior, R. L. (2005). The chemistry behind antioxidant capacity assays. Journal of Agricultural and Food Chemistry, 53(6), 1841-1856.

19. Jinsmaa, Y., \& Yoshikawa, M. (1999). Enzymatic release of neocasomorphin and $\beta$-casomorphin from bovine $\beta$-casein. Peptides, 20(8), 957-962.

20. Kalyan, S., Meena, S., Kapila, S., Sowmya, K., \& Kumar, R. (2018). Evaluation of goat milk fat and goat milk casein fraction for anti-hypercholesterolaemic and antioxidative properties in hypercholesterolaemic rats. International Dairy Journal, 84, 23-27.

21. Kašparová, S., Brezová, V., Valko, M., Horecký, J., Mlynárik, V., Liptaj, T., \& Dobrota, D. (2005). Study of the oxidative stress in a rat model of chronic brain hypoperfusion. Neurochemistry International, 
46(8), 601-611.

22. Kitts, D. D. (1994). Bioactive substances in food: identification and potential uses. Canadian Journal of Physiology and Pharmacology, 72(4), 423-434.

23. Korhonen, H., \& Pihlanto, A. (2006). Bioactive peptides: production and functionality. International Dairy Journal, 16(9), 945-960.

24. Kullisaar, T., Songisepp, E., Mikelsaar, M., Zilmer, K., Vihalemm, T., \& Zilmer, M. (2003). Antioxidative probiotic fermented goats' milk decreases oxidative stress-mediated atherogenicity in human subjects. British Journal of Nutrition, 90(2), 449-456.

25. Kusumaningtyas, E., Widiastuti, R., Kusumaningrum, H. D., \& Suhartono, M. T. (2016). Antibacterial and antioxidant activities of goat milk hydrolysate generated by bacillus sp. E, 13, 105-110.

26. Laemmli, U. K. (1970). Cleavage of structural proteins during the assembly of the head of bacteriophage T4. Nature, 227(5259), 680-685.

27. Li, Z., Jiang, A., Yue, T., Wang, J., Wang, Y., \& Su, J. (2013). Purification and identification of five novel antioxidant peptides from goat milk casein hydrolysates. Journal of Dairy Science, 96(7), 4242-4251.

28. Meena, S., Rajput, Y. S., \& Sharma, R. (2014). Comparative fat digestibility of goat, camel, cow and buffalo milk. International Dairy Journal, 35(2), 153-156.

29. Meena, S., Rajput, Y. S., Sharma, R., \& Singh, R. (2019). Effect of goat and camel milk vis a vis cow milk on cholesterol homeostasis in hypercholesterolemic rats. Small Ruminant Research, 171, 8-12.

30. Ming, Y., \& Zhi-he, H. (2012). Separation and purification of ACE inhibitory peptides from casein hydrolysate by two enzymes. Food Science, 33, 50-53.

31. Mudgil, P., Kamal, H., Yuen, G. C., \& Maqsood, S. (2018). Characterization and identification of novel antidiabetic and anti-obesity peptides from camel milk protein hydrolysates. Food Chemistry, 259, 46-54.

32. Niero, G., Currò, S., Costa, A., Penasa, M., Cassandro, M., Boselli, C., Giangolini, G., \& De Marchi, M. (2018). Phenotypic characterization of total antioxidant activity of buffalo, goat, and sheep milk. Journal of Dairy Science, 101(6), 4864-4868.

33. Nozière, P., Grolier, P., Durand, D., Ferlay, A., Pradel, P., \& Martin, B. (2006). Variations in carotenoids, fat-soluble micronutrients, and color in cows' plasma and milk following changes in forage and feeding level. Journal of Dairy Science, 89(7), 2634-2648.

34. Olsen, J. V., Ong, S. E., \& Mann, M. (2004). Trypsin cleaves exclusively C-terminal to arginine and lysine residues. Molecular \& Cellular Proteomics, 3(6), 608-614.

35. Ou, B., Huang, D., Hampsch-Woodill, M., Flanagan, J. A., \& Deemer, E. K. (2002). Analysis of antioxidant activities of common vegetables employing oxygen radical absorbance capacity (ORAC) and ferric reducing antioxidant power (FRAP) assays: a comparative study. Journal of Agricultural and Food Chemistry, 50(11), 3122-3128.

36. Pardo, M. F., \& Natalucci, C. L. (2002). Electrophoretic analysis (Tricine-SDS-PAGE) of bovine caseins. Acta Farmacéutica Bonaerense, 21(1), 57-60. 
37. Park, Y. W. (2009). Bioactive components of goat milk. In: Park Y W (Eds.) Bioactive Components in Milk and Dairy Products. Blackwell Publishers, Ames, lowa and Oxford, England, pp. 43-82.

38. Park, Y. W., \& Haenlein, G. F. (2008). Therapeutic and Hypoallergenic Values of Goat Milk and Implication of Food Allergy. In: Park Y W and Haenlien G F W (Eds.) Handbook of Milk of Non-bovine Mammals. Blackwell Publishers, Ames, lowa and Oxford, England, pp. 121-136.

39. Pihlanto, A. (2006). Antioxidative peptides derived from milk proteins. International Dairy Journal, 16(11), 1306-1314.

40. Power, O., Jakeman, P., \& FitzGerald, R. J. (2013). Antioxidative peptides: enzymatic production, in vitro and in vivo antioxidant activity and potential applications of milk-derived antioxidative peptides. Amino Acids, 44(3), 797-820.

41. Rajesh, K., Varun, S., Sangwan, R. B., \& Bimlesh, M. (2010). Comparative studies on antioxidant activity of buffalo and cow milk casein and their hydrolysates. Milchwissenschaft, 65(3), 287-290.

42. Re, R., Pellegrini, N., Proteggente, A., Pannala, A., Yang, M., \& Rice-Evans, C. (1999). Antioxidant activity applying an improved ABTS radical cation decolorization assay. Free Radical Biology and Medicine, 26(9-10), 1231-1237.

43. Santillo, A., Kelly, A. L., Palermo, C., Sevi, A., \& Albenzio, M. (2009). Role of indigenous enzymes in proteolysis of casein in caprine milk. International Dairy Journal, 19(11), 655-660.

44. Segura-Campos, M. R., Chel-Guerrero, L. A., \& Betancur-Ancona, D. A. (2011). Purification of angiotensin I-converting enzyme inhibitory peptides from a cowpea (Vigna unguiculata) enzymatic hydrolysate. Process Biochemistry, 46(4), 864-872.

45. Shanmugam, V. P., Kapila, S., Sonfack, T. K., \& Kapila, R. (2015). Antioxidative peptide derived from enzymatic digestion of buffalo casein. International Dairy Journal, 42, 1-5.

46. Simos, Y., Metsios, A., Verginadis, I., D’Alessandro, A. G., Loiudice, P., Jirillo, E., Charalampidis, P., ... \& Karkabounas, S. (2011). Antioxidant and anti-platelet properties of milk from goat, donkey and cow: An in vitro, ex vivo and in vivo study. International Dairy Journal, 21(11), 901-906.

47. Smith, P. E., Krohn, R. I., Hermanson, G. T., Mallia, A. K., Gartner, F. H., Provenzano, M., Fujimoto, E. K., Goeke, N. M., Olson, B. J., \& Klenk, D. C. (1985). Measurement of protein using bicinchoninic acid. Analytical Biochemistry, 150(1), 76-85.

48. Sun, Q., Shen, H., \& Luo, Y. (2011). Antioxidant activity of hydrolysates and peptide fractions derived from porcine hemoglobin. Journal of Food Science and Technology, 48(1), 53-60.

49. Thaipong, K., Boonprakob, U., Crosby, K., Cisneros-Zevallos, L., \& Byrne, D. H. (2006). Comparison of ABTS, DPPH, FRAP, and ORAC assays for estimating antioxidant activity from guava fruit extracts. Journal of Food Composition and Analysis, 19(6-7), 669-675.

50. Valko, M., Leibfritz, D., Moncol, J., Cronin, M. T., Mazur, M., \& Telser, J. (2007). Free radicals and antioxidants in normal physiological functions and human disease. The International Journal of Biochemistry \& Cell Biology, 39(1), 44-84.

51. Yu, B. P. (1994). Cellular defenses against damage from reactive oxygen species. Physiological Reviews, 74(1), 139-162. 
52. Zhidong, L., Benheng, G., Xuezhong, C., Zhenmin, L., Yun, D., Hongliang, H., \& Wen, R. (2013). Optimisation of hydrolysis conditions for antioxidant hydrolysate production from whey protein isolates using response surface methodology. Irish Journal of Agricultural and Food Research, 53-65.

53. Zulueta, A., Maurizi, A., Frígola, A., Esteve, M. J., Coli, R., \& Burini, G. (2009). Antioxidant capacity of cow milk, whey and deproteinized milk. International Dairy Journal, 19(6-7), 380-385.

\section{Tables}

Table 1. TEAC $(\mu \mathrm{M})$ of goat, cow and buffalo raw milk

\begin{tabular}{|l|c|c|c|}
\hline \multicolumn{1}{r|}{ Milk } & Goat & Cow & Buffalo \\
\hline ABTS & & & \\
\hline ORAC & $5416 \pm 18.11^{\mathrm{a}}$ & $5430 \pm 39.48^{\mathrm{a}}$ & $5571 \pm 32.32^{\mathrm{b}}$ \\
\hline FRAP & $0.314 \pm 0.015^{\mathrm{a}}$ & $0.283 \pm 0.004^{\mathrm{ab}}$ & $0.262 \pm 0.006^{\mathrm{b}}$ \\
\hline DPPH & $180.3 \pm 2.779^{\mathrm{a}}$ & $131.9 \pm 0.913^{\mathrm{b}}$ & $207.3 \pm 10.80^{\mathrm{c}}$ \\
\hline
\end{tabular}

Values are expressed as mean $\pm \operatorname{SEM}(\mathrm{n}=3)$.

Dissimilar superscript alphabets indicate significant differences $(\mathrm{P}<0.05)$.

Table 2. TEAC ( $\mu \mathrm{M})$ of goat raw, pasteurized and boiled milk

\begin{tabular}{|c|c|c|c|}
\hline Milk & Goat raw (GR) & Goat pasteurized (GP) & Goat Boiled (GB) \\
\hline ABTS & $5416 \pm 18.11^{\mathrm{a}}$ & $4964 \pm 36.44^{\mathrm{b}}$ & $4749 \pm 21.22^{\mathrm{c}}$ \\
\hline ORAC & $4135 \pm 2.64^{\mathrm{a}}$ & $4076 \pm 35.02^{\mathrm{a}}$ & $4052 \pm 40.53^{\mathrm{a}}$ \\
\hline FRAP & $0.314 \pm 0.01^{\mathrm{a}}$ & $0.301 \pm 0.00^{\mathrm{ab}}$ & $0.294 \pm 0.00^{\mathrm{b}}$ \\
\hline DPPH & $180.3 \pm 2.77^{\mathrm{a}}$ & $166.2 \pm 6.39^{\mathrm{b}}$ & $151.6 \pm 3.19^{\mathrm{c}}$ \\
\hline
\end{tabular}

Values are expressed as mean $\pm \operatorname{SEM}(n=3)$.

Dissimilar superscript alphabets indicate significant differences $(\mathrm{P}<0.05)$ in each row 
Table 3. TEAC values ( $\mu \mathrm{mol} / \mathrm{mg}$ ) of casein and its hydrolysates by different assays

\begin{tabular}{|c|c|c|c|c|c|c|c|c|}
\hline $\begin{array}{c}\text { Groups } \\
\text { Assay }\end{array}$ & Casein & P & T & C & PT & PC & TC & PTC \\
\hline ABTS & $0.528 \pm$ & $0.736 \pm$ & $0.749 \pm$ & $0.772 \pm$ & $0.7830 \pm$ & $0.805 \pm$ & $0.745 \pm$ & $0.799 \pm$ \\
& $0.008^{\mathrm{a}}$ & $0.006^{\mathrm{b}}$ & $0.008^{\mathrm{b}}$ & $0.007^{\mathrm{bc}}$ & $0.021^{\mathrm{c}}$ & $0.009^{\mathrm{c}}$ & $0.015^{\mathrm{b}}$ & $0.009^{\mathrm{bc}}$ \\
\hline \multirow{2}{*}{ ORAC } & $0.347 \pm$ & $0.402 \pm$ & $0.396 \pm$ & $0.383 \pm$ & $0.373 \pm$ & $0.368 \pm$ & $0.352 \pm 0$. & $0.364 \pm$ \\
& $0.003^{\mathrm{a}}$ & $0.006^{\mathrm{b}}$ & $0.004^{\mathrm{bd}}$ & $0.004^{\mathrm{cd}}$ & $0.0003^{\mathrm{c}}$ & $0.002^{\mathrm{c}}$ & $004^{\mathrm{ac}}$ & $0.001^{\mathrm{ac}}$ \\
\hline DPPH (x & $1.590 \pm$ & $2.745 \pm$ & $4.152 \pm$ & $2.768 \pm$ & $4.373 \pm$ & $2.814 \pm$ & $4.381 \pm$ & $3.960 \pm$ \\
$\left.\mathbf{1 0}^{-3}\right)$ & $0.175^{\mathrm{a}}$ & $0.074^{\mathrm{b}}$ & $0.047^{\mathrm{c}}$ & $0.115^{\mathrm{b}}$ & $0.140^{\mathrm{c}}$ & $.153^{\mathrm{b}}$ & $0.066^{\mathrm{c}}$ & $0.096^{\mathrm{c}}$ \\
\hline
\end{tabular}

Values are expressed as mean \pm SEM $(\mathrm{n}=3)$.

Dissimilar superscript alphabets indicate significant differences $(\mathrm{P}<0.05)$.

Figures

\section{PEPSIN TRYPSIN HYDROLYSATE}

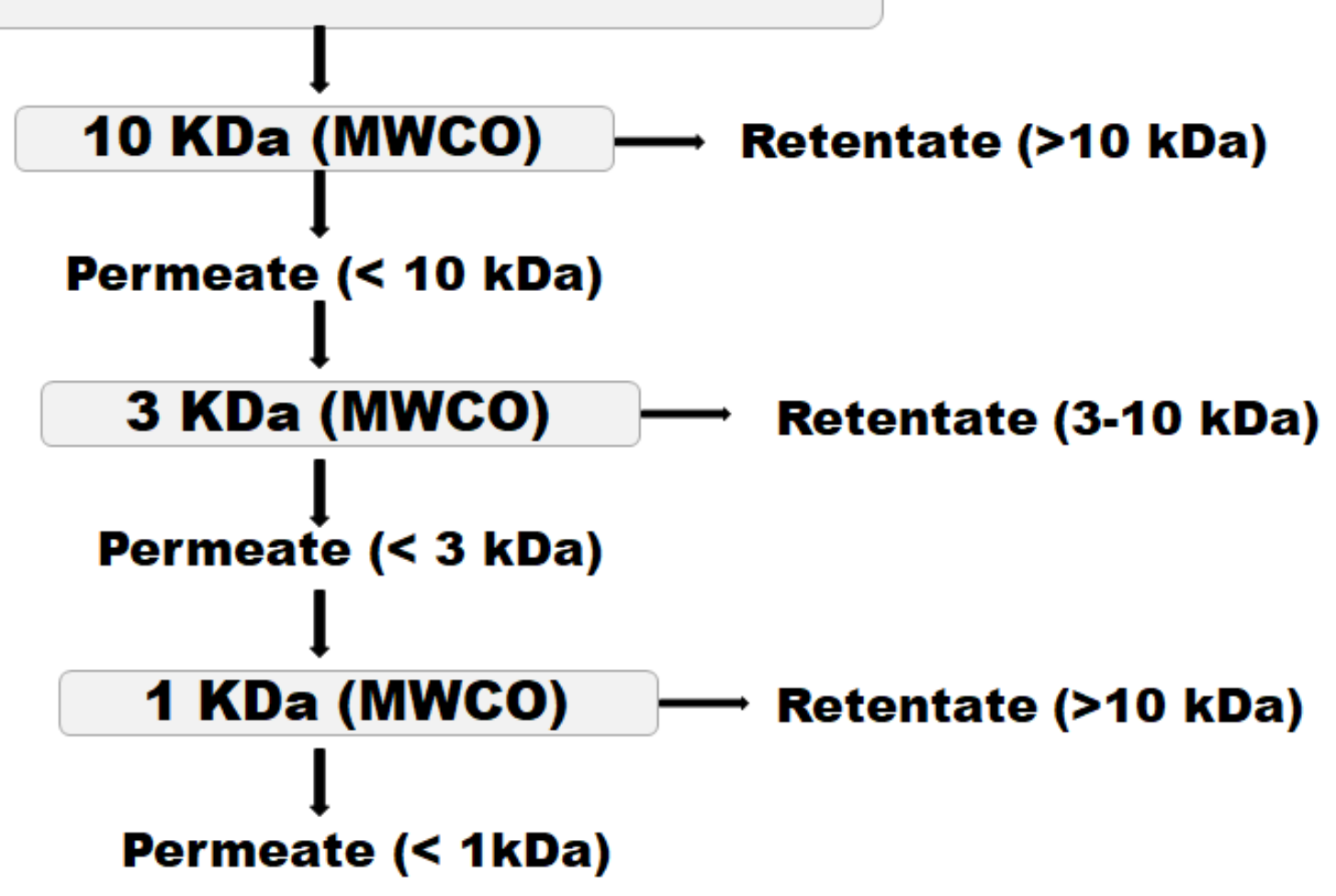

Figure 1

Flow chart for ultrafiltration of pepsin-trypsin hydrolysates of casein by 10, 3 and $1 \mathrm{kDa}$ filters 


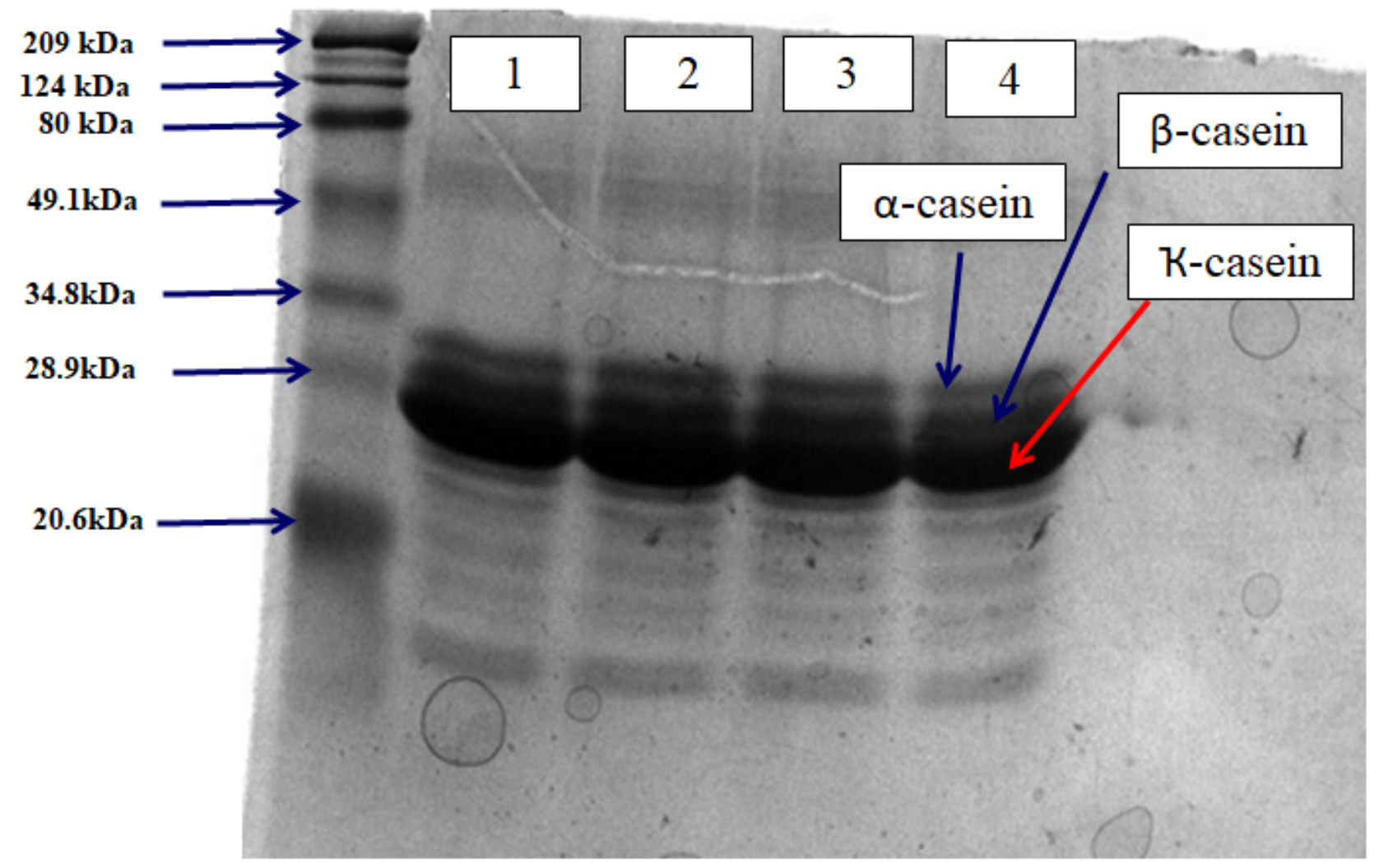

Figure 2

SDS-PAGE of Isoelectric Casein isolates (Lane 1 - Low molecular weight markers: Myosin (209 kDa), $\beta$ galactosidase (124 kDa), Bovine serum albumin (80 kDa), Ovalbumin (49.1 kDa), Carbonic anhydrase (34.8 kDa), Soybean trypsin inhibitor $(28.9 \mathrm{kDa})$ and Lysozyme $(20.6 \mathrm{kDa})$ from top to bottom; Lane 2-5 Casein) 


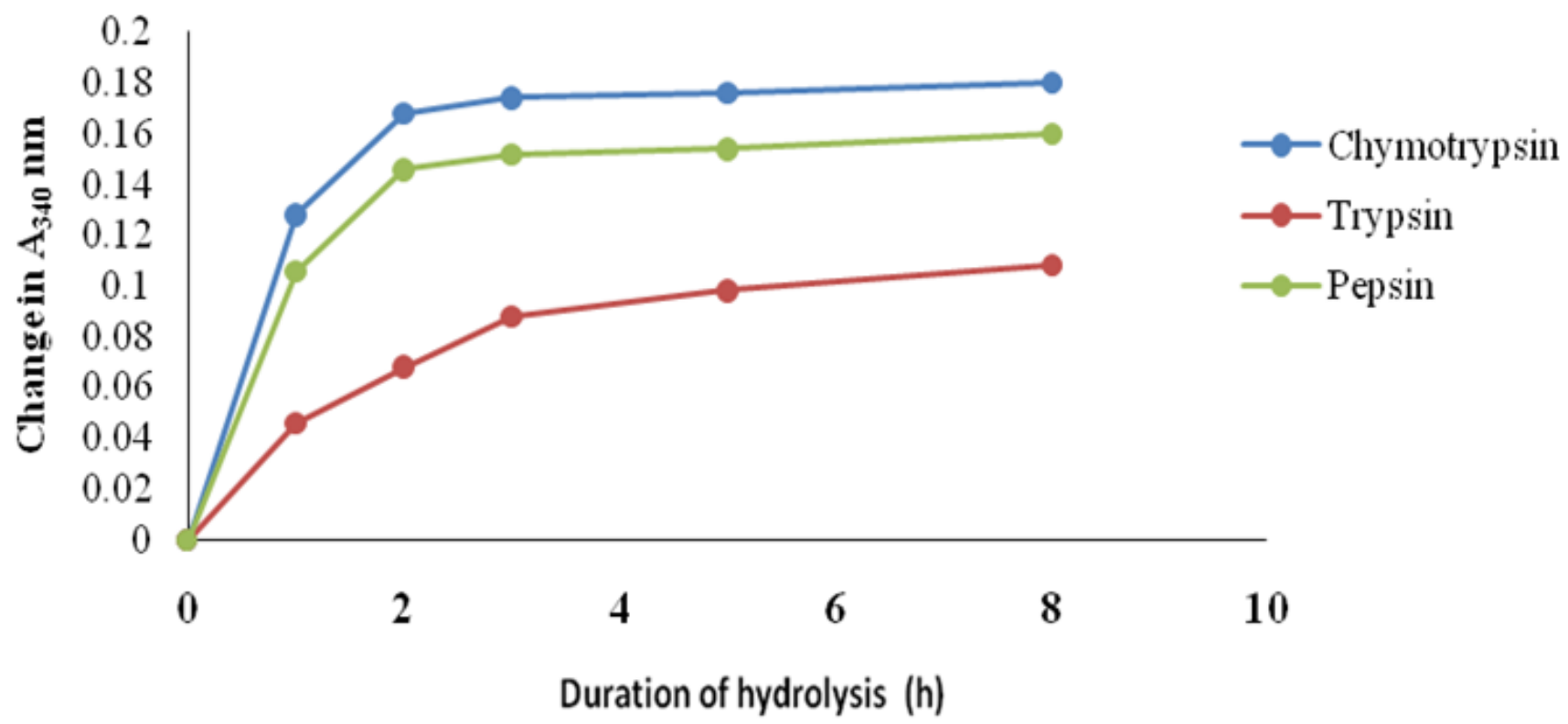

Figure 3

Rate of hydrolysis of casein by pepsin (P), trypsin ( $T$ ) and chymotrypsin (C).

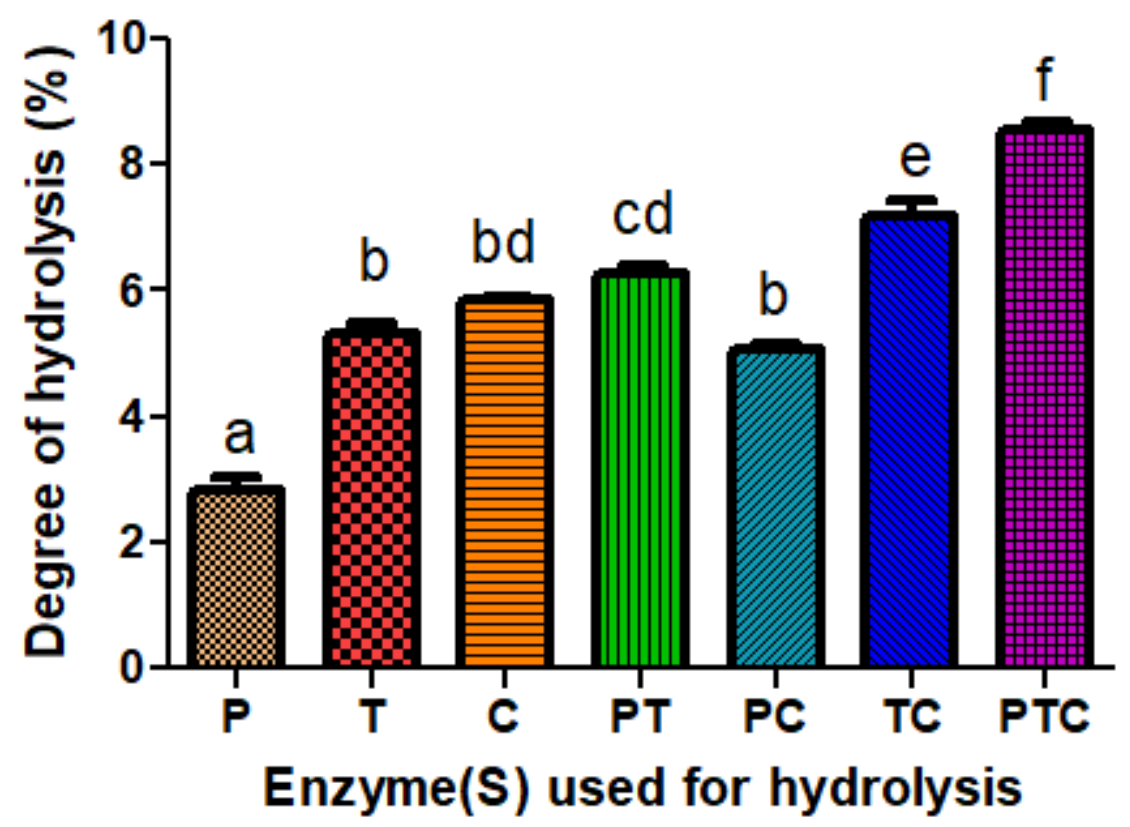

Figure 4

(a) Degree of hydrolysis of casein hydrolyzed by pepsin (P), trypsin (T), chymotrypsin (C) and their combinations (PT, PC, TC and PTC) as estimated by OPA method. Values expressed are mean \pm S.E.M. ( $\mathrm{n}$ 
$=3)$. Dissimilar superscript alphabets indicate significant differences $(P<0.05)$.

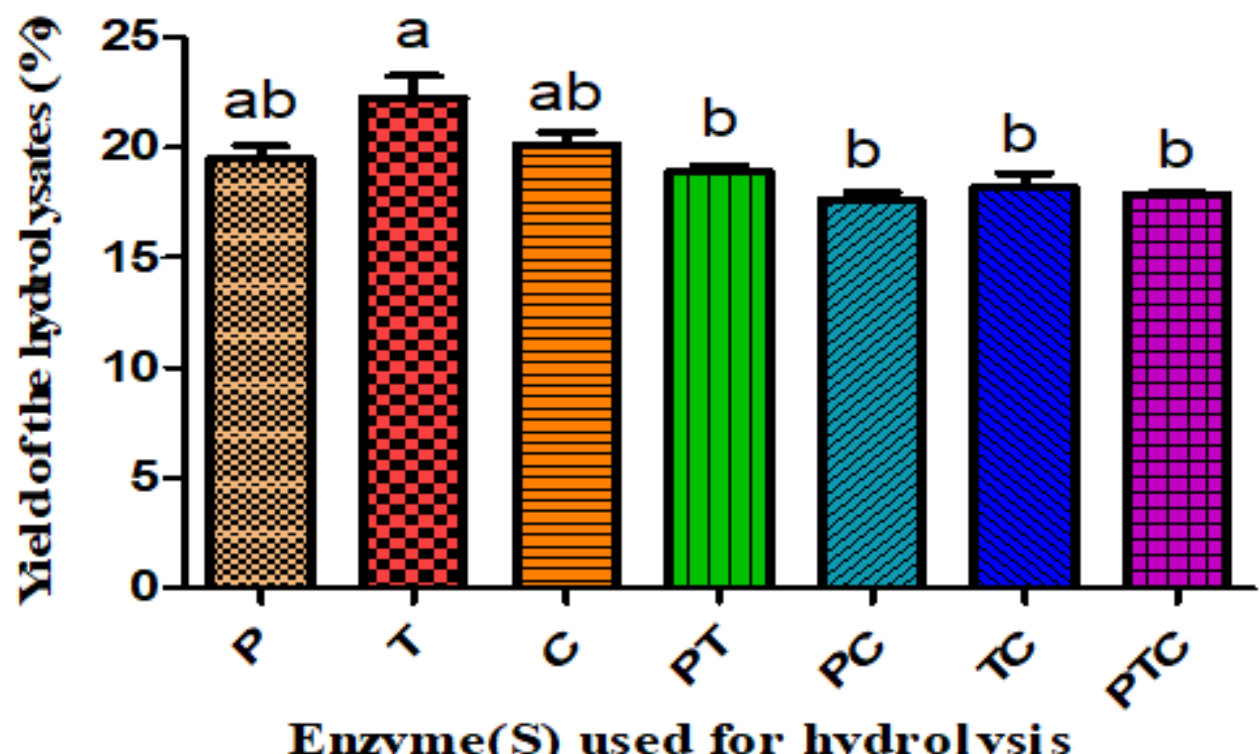

Figure 5

Yield (\%) of casein hydrolyzed by P, T, C, PT, PC, TC, and PTC. Values expressed as Mean \pm S.E.M. $(n=3)$. The bars bearing different letters differ significantly $(P<0.05)$.

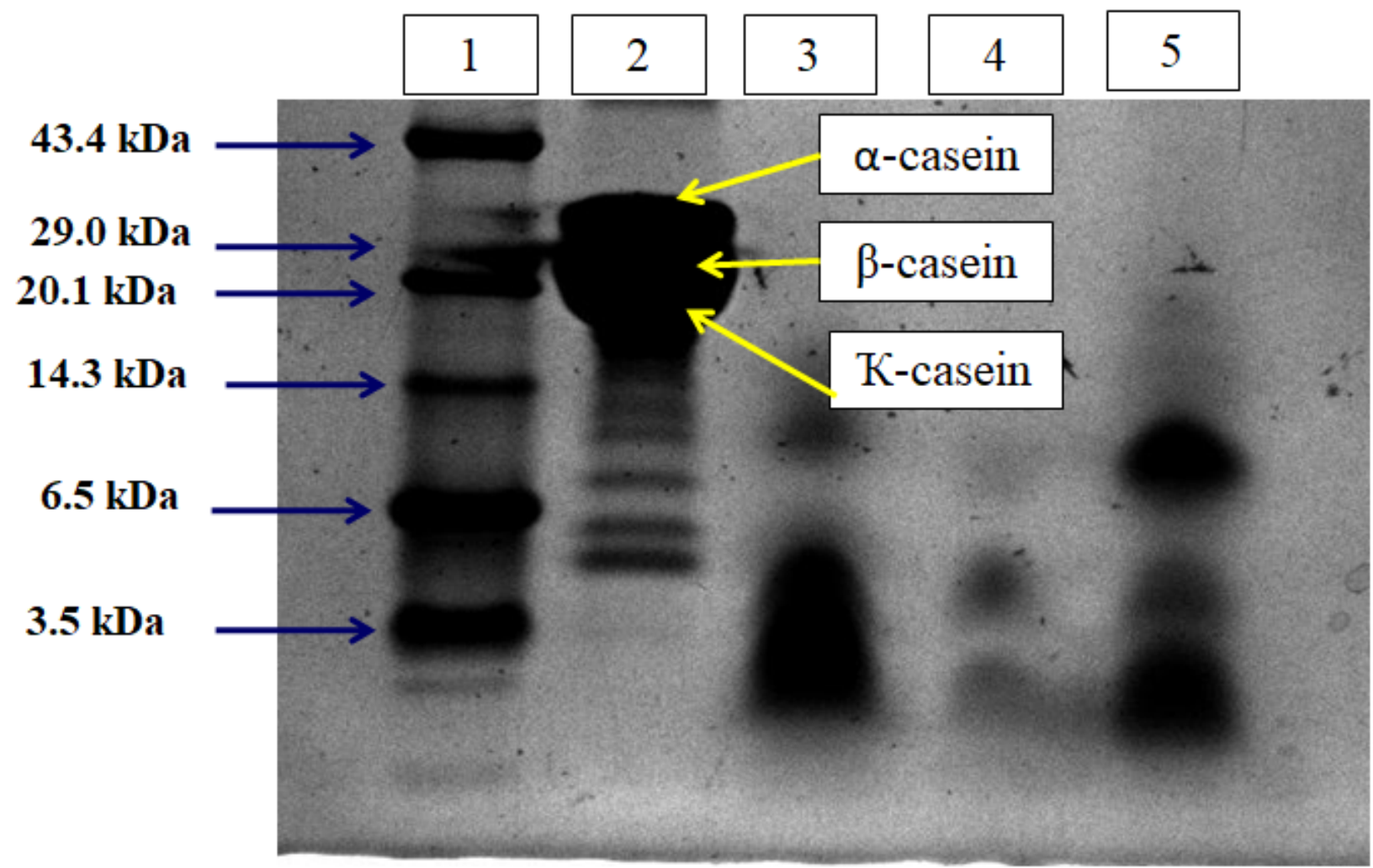


Figure 6

Tricine SDS-PAGE of casein and its hydrolysates. (Lane 1 - Low molecular weight markers; Lane 2 Casein; Lane 3 - Casein hydrolyzed by pepsin; Lane 4 - Casein hydrolyzed by trypsin; Lane 5 - Casein hydrolyzed by chymotrypsin)

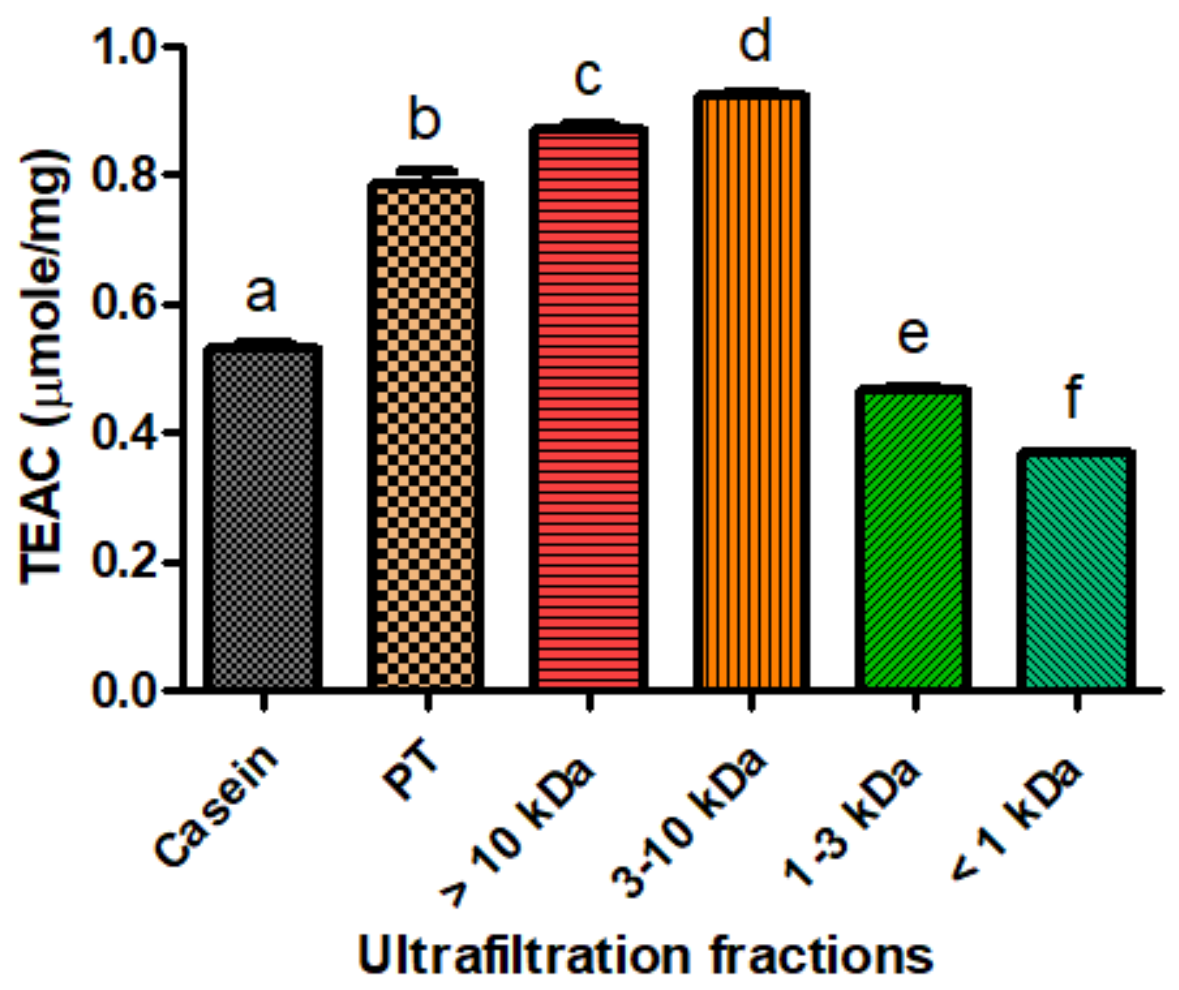

Figure 7

Antioxidant activity of different fractions ( $>10 \mathrm{kDa}, 3-10 \mathrm{kDa}, 1-3 \mathrm{kDa} \&<1 \mathrm{kDa}$ ) of pepsin-trypsin (PT) hydrolysates. Values expressed as Mean \pm S.E.M. $(n=3)$. The bars bearing different alphabets differ significantly $(P<0.05)$. 